\title{
Pengaruh Sosialisasi Perpajakan, Pengetahuan Perpajakan dan Perhitungan Tarif Pajak pada Kepatuhan Pajak Mahasiswa Pelaku UMKM
}

\author{
Komang Putra Suardana ${ }^{1}$ \\ Fakultas Ekonomi dan Bisnis \\ Universitas Udayana, Indonesia
}

\author{
Gayatri $^{2}$ \\ Fakultas Ekonomi dan Bisnis \\ Universitas Udayana, Indonesia
}

Surel : putrasuardana07@gmail.com

\section{ABSTRAK}

Tujuan dari penelitian ini adalah untuk mengetahui pengaruh sosialisasi perpajakan, pengetahuan perpajakaetn, dan perhitungan tarif pajak pada kepatuhan pajak mahasiswa pelaku UMKM. Penelitian ini dilakukan di Program Studi Akuntansi Fakultas Ekonomi dan Bisnis Universitas Udayana, dengan menggunakan sampling jenuh. Dimana jumlah sampel dalam penelitain ini adalah 30 orang, yaitu seluruh populasi mahasiswa progam studi akuntansi angkatan 2016 dan 2017 yang memiliki bisnis dijadikan sampel. Metode pemilihan sampel menggunakan teknik purposive sampling. Teknik analisis yang digunakan adalah Analisis Regresi Linier Berganda. Hasil penelitian menemukan bahwa sosialisasi perpajakan, pengetahuan perpajakan dan perhitungan tarif pajak berpengaruh pada kepatuhan pajak mahasiswa pelaku UMKM.

Kata Kunci: Sosialisasi; Pengetahuan; Tarif; Kepatuhan Pajak.

\section{The Effects of Taxation Socialization, Taxation Knowledge, and Calculation of Tax Rates on Student Tax Compliance as SMEs}

\section{ABSTRACT}

The purpose of this study is to study the interaction of tax socialization, tax knowledge, and calculation of tax rates at the level of tax collection of students as SMEs. This research was conducted at the Accounting Study Program of the Faculty of Economics and Business, Udayana University, using a saturated sample. Where the number of samples in this study were 30 people, namely the entire population of accounting studies program students in 2016 and 2017 who have a business producing samples. The sample selection method uses a purposive sampling technique. The analysis technique used is Multiple Linear Regression Analysis. The results found that taxation socialization, tax knowledge, and calculation of tax rates at the level of tax participation of students as SMEs.

Keywords: $\quad$ Socialization; Knowledge; Rates; Tax Compliance.

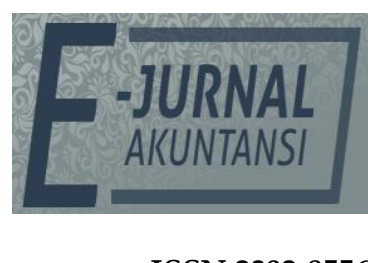

e-ISSN 2302-8556

Vol. 30 No. 9

Denpasar, September 2020 Hal. 2311-2322

DOI:

10.24843/EJA.2020.v30.i09.p11

PENGUTIPAN:

Suardana, K. P. \& Gayatri (2020). Pengaruh Sosialisasi Perpajakan, Pengetahuan Perpajakan dan Perhitungan Tarif Pajak pada Kepatuhan

Pajak Mahasiswa Pelaku UMKM. E-Jurnal Akuntansi, 30(9), 2311-2322

RIWAYAT ARTIKEL: Artikel Masuk: 15 Mei 2020 Artikel Diterima: 22 Juli 2020

Artikel dapat diakses : https://ojs.unud.ac.id/index.php/Akuntansi/index 


\section{PENDAHULUAN}

Pajak merupakan pendapatan negara yang didapatkan dari masyarakat dan pajak juga memiliki pengaruh yang besar bagi pembangunan negara, karena pendapatan dari pajak merupakan pendapatan yang sangat potensial. Penggunaan perpajakan yang tepat mengarah pada katan antara pemerintah dan rakyat suatu negara serta memastikan bahwa biaya dan manfaat pembangunan dibagi secara adil (Akinboade, 2015). Pendapatan yang dikumpulkan dari pajak memungkinkan suatu negara untuk menyediakan layanan bagi masyarakat dan pengembangan ekonomi Negara tersebut (Gitaru, 2016). Oleh karena tu kesejahteraan masyarakat dan pembangunan nasional sangat dipengaruhi oleh peran dari pendapatan sektor pajak. Pendapatan yang dimobilisasi dari pajak merupakan pendanaan utama untuk pengeluaran pemerintah (Kuug, 2016). Tinggi rendahnya kepatuhan wajib pajak akan mempengaruhi penerimaan pajak dari tahun ke tahun. Oleh karena tu kesadaran dari masyarakat utuk membayar pajak sangat diperlukan. (Astina, 2018).

Tabel 1. Perkembangan Penerimaan Pajak (Dalam Miliar Rupiah)

\begin{tabular}{lcccl}
\hline No & Tahun & Target & Realisasi & Capaian \\
\hline 1 & 2016 & $1.355,20$ & $1.105,73$ & $81,96 \%$ \\
2 & 2017 & $1.283,57$ & $1.151,03$ & $89,67 \%$ \\
3 & 2018 & $1.424,00$ & $1.315,51$ & $92,23 \%$ \\
4 & 2019 & $1.577,56$ & $1.332,06$ & $84,44 \%$ \\
\hline
\end{tabular}

Sumber: Laporan Kinerja Direktorat Jendral Pajak, 2019

Berdasarkan Tabel 1, tersebut dapat dilihat perkembangan penerimaan pajak di ndonesia selalu mengalamai kenaikan, namun tidak pernah mencapai target yang telah ditetapkan berdasarkan Anggaran Pendapatan dan Belanja Negara (APBN). Bahkan persentase capaian pada tahun 2019 mengalami penurunan dibandingkan tahun sebelumnya. Penurunan capaian ni menunjukkan bahwa penerimaan pajak di ndonesia masih belum maksimal. Penerimaan pajak yang belum maksimal ni disebabkan oleh tingkat kepatuhan masyarakat di ndonesia dalam memenuhi kewajiban pajaknya masih rendah.

Banyak faktor yang mempengaruhi kesadaran dan kepatuhan wajib pajak dalam memenuhi kewajiban perpajakannya, baik faktor eksternal maupun faktor internal. Sosialisasi perpajakan merupakan salah satu faktor eksternal yang mempengaruhi kepatuhan wajib pajak Sosialisasi pajak yang intensif dapat meningkatkan pemahaman wajib pajak tentang semua hal yang berkaitan dengan perpajakan, termasuk fungsi pajak, peraturan, mekanisme, dan sanksi yang akan diperoleh wajib pajak jika tidak memenuhi kewajiban pajaknya (Setyorini, 2016). Sosialisasi pajak dapat dilakukan penyuluhan pajak berupa Informasi berbasis teks seperti pamflet, iklan, dan situs web adalah metode paling efektif dalam membantu wajib pajak untuk memenuhi kewajiban perpajakannya. Metode-metode ini juga dirasakan efektif sebagai media pendidikan pajak (Hassan et al., 2016). Kegiatan penyuluhan pajak memiliki andil besar dalam menyukseskan sosialisasi pajak ke seluruh wajib pajak (Burhan, 2015). Jika wajib 
pajak diberikan pemahaman yang baik dan benar melalui sosialisasi, maka wajib pajak akan memiliki pengetahuan tentang pentingnya membayar pajak (Wardani \& Wati, 2018).

Pengetahuan perpajakan merupakan salah satu faktor internal yang mempengaruhi kepatuhan wajib pajak. Pengetahuan perpajakan adalah kemampuan sesorang wajib pajak dalam mengetahui peraturan perpajakan baik itu soal tarif pajak berdasarkan undang-undang yang akan dibayarkan, maupun maanfaat pajak yang akan berguna bagi kehidupan mereka (Yulsiati, 2015). Sikap wajib pajak dapat ditingkatkan melalui pengetahuan perpajakan yang lebih baik sehingga dapat meningkatkan kepatuhan dan mengurangi kecenderungan untuk menghindari pajak (Inasius, 2015). Pengetahuan perpajakan yang wajib pajak miliki akan membuat mereka mengetahui alur uang pembayaran pajak serta manfaat pajak yang akan mereka dapatkan (Yusnidar et al., 2015). Dengan meningkatnya pengetahuan perpajakan masyarakat melalui pendidikan perpajakan baik formal maupun non formal akan berdampak positif terhadap pemahaman dan kesadaran wajib pajak dalam membayar pajak (Adi, 2018). Peningkatan tingkat pengetahuan perpajakan dapat menyebabkan meningkatnya tingkat kepatuhan wajib pajak, selain itu peningkatan kesadaran wajib pajak sehubungan dengan kewajiban pajak dapat lebih ditingkatkan melalui peningkatan layanan pendidikan pajak dan bukan hanya sekedar memberikan mereka pedoman sederhana tentang tata cara mengisi formulir pajak (Manual \& Zhi Xin, 2016).

Mahasiswa adalah fase dimana seseorang telah dikategorikan pada fase siap kerja, dimana setelah mereka tamat dari bangku kuliah mereka akan menjadi calon pekerja yang nantinya akan membayar pajak, baik sebagai karyawan ataupun wirausahawan. Bahkan di zaman sekarang ni, banyak mahasiswa yang telah menjadi seorang wirausahawan dengan memiliki berbagai lini bisnis dan telah memiliki karyawan. Oleh karena itu mahasiswa yang memiliki bisnis juga memiliki kewajiban untuk melaporkan pendapatan serta melaksanakan kewajiban pajaknya. Pendidikan tentang pengetahuan perpajakan harus segera diberikan kepada mahasiswa, mungkin sebagai mata pelajaran pilihan dalam perguruan tinggi sehingga mahasiswa dapat menyadari tanggung jawab mereka sebagai pembayar pajak di masa depan (Newman \& Nokhu, 2018). Mahasiswa yang menjadi wirausahawan atau memiliki bisnis termasuk dalam sektor kategori pengusaha Usaha Mikro Kecil dan Menengah atau disebut UMKM. Sektor UMKM telah berhasil menjadi sumber penggerak ekonomi baru di Indonesia. Sektor UMKM telah berhasil menjadi sumber penggerak ekonomi baru di Indonesia. UMKM mampu menciptakan lapangan kerja, membantu dalam perdagangan internasional, menyediakan layanan dan dukungan untuk perusahaan besar serta membantu dalam diversifikasi ekonomi (Aladejebi, 2018). Kepatuhan pelaku UMKM terhadap undang-undang dan peraturan perpajakan akan berkontribusi pada peningkatan pendapatan pemerintah (Wahabu, 2017). Namun sayangnya peraturan pajak yang kompleks dan juga perhitungan tarif pajak yang tinggi membuat banyak UMKM enggan dalam membayar kewajiban perpajakannya. Tingkat ketidakpatuhan pajak yang masih tinggi pada sektor UMKM ini dapat menghambat perkembangan perekonomian negara (Dlamini, 
2017). Oleh karena tu, pemerintah terkadang mengubah peraturan dan undangundang perpajakan dari perubahan tarif sampai dengan perubahan syaratsyaratnya (Angelia \& Fajriana, 2018).

Perhitungan tarif pajak juga merupakan salah satu faktor eksternal yang mempengaruhi kepatuhan wajib pajak. Perhitungan tarif pajak adalah persentase yang digunakan sebagai dasar dalam menghitung jumlah pajak yang harus disetor (Cahyani \& Noviari, 2019). Oleh karena itu pemerintah membuat peraturan pada bulan Juli 2018 bahwa perhitunga tarif pajak pada UMKM dikenakan PPh Final yaitu 0,5\% dan perubahan tersebut diatur dan tertuang dalam Peraturan Pemerintah No. 23 Tahun 2018 dimana sebelumnya perhitungan tarif pajak untuk UMKM dikenakan PPh Final 1\% yang diatur dalam Peraturan Pemerintah Nomor 46 Tahun 2013. Tentunya dengan penurunan tarif tersebut dapat memberikan keadilan bagi wajib pajak UMKM dan tidak mengakibatkan kerugian bagi UMKM yang memiliki omzet yang rendah.

Teori atribusi menyatakan bahwa bila individu-individu mengamati perilaku seseorang, mereka mencoba menentukan pengaruh internal dan eksternal yang menimbulkan perilaku tersebut (Suntono \& Kartika, 2015). Penelitian ini menggunakan teori atribusi karena dalam penelitian ini akan dilakukan studi untuk mengetahui apakah terdapat pengaruh sosialisasi perpajakan, pengetahuan perpajakan dan perhitungan tarif pajak pada kepatuhan pajak mahasiswa pelaku UMKM. Faktor yang akan diteliti adalah faktor eksternal yaitu sosialisasi perpajakan dan perhitungan tarif pajak serta faktor internal yaitu pengetahuan perpajakan.

Berdasarkan teori atribusi, sosialisasi perpajakan merupakan salah satu faktor eksternal yang mempengaruhi kepatuhan pajak. Sosialisasi yang tepat akan meningkatkan pengetahuan wajib pajak atas peraturan baru sehingga informasi yang disampaikan dalam sosialisasi akan berdampak pada kepatuhan wajib pajak. Upaya sosialisasi pajak dapat dilakukan melalui penyebaran informasi tentang jenis-jenis pajak, tarif pajak, mekanisme pembayaran pajak dan manfaat pajak (Mukhlis et al., 2015). Menurut penelitian Faizin et al., (2016) dan Wulandari et al., (2015) mengungkapkan sosialisasi perpajakan berpengaruh terhadap kepatuhan wajib pajak.

Berdasarkan uraian tersebut, maka hipotesis yang dikembangkan dalam penelitian ini sebagai berikut.

$\mathrm{H}_{1}$ : Sosialisasi perpajakan berpengaruh pada kepatuhan pajak mahasiswa pelaku UMKM.

Berdasarkan teori atribusi, pengetahuan perpajakan merupakan salah satu faktor internal yang mempengaruhi tingkat kepatuhan pajak. Dengan Memiliki pengetahuan pajak akan mendapatkan banyak keuntungan karena menghemat wajib pajak dalam mempekerjakan konsultan untuk menghitung pajak bagi bisnis mereka serta dapat menghemat biaya konsultasi pajak yang besar (Oladipupo \& Obazee, 2016). Selain itu mahasiswa pelaku UMKM akan paham mengenai peraturan perpajakan yang berlaku. Semakin tinggi tingkat pengetahuan mahasiswa akan perpajakan maka tingkat kepatuhannya dalam memenuhi kewajiban perpajakannya akan meningat karena mereka akan mengetahui tata cara perhitungan serta konsekuensi atau sanksi yang akan didapatkan apabila tidak memenuhi kewajiban perpajakannya. Penelitian yang dilakukan oleh 
(Fatmawati, 2015) dan (Cahyani \& Noviari, 2019) menyatakan bahwa pengetahuan perpajakan berpengaruh positif terhadap kepatuhan wajib pajak UMKM.

Berdasarkan uraian tersebut, maka hipotesis yang dikembangkan dalam penelitian ini sebagai berikut.

$\mathrm{H}_{2}$ : Pengetahuan perpajakan berpengaruh pada kepatuhan pajak mahasiswa pelaku UMKM.

Berdasarkan teori atribusi, perhitungan tarif pajak merupakan salah satu faktor eksternal yang mempengaruhi tingkat kepatuhan pajak. Tarif pajak merupakan angka atau persentase yang digunakan untuk menghitung jumlah pajak yang terhitung. Perhitungan tarif pajak UMKM saat ini adalah 0.5\%, penurunan tarif ini bertujuan untuk memberikan motivasi wajib pajak untuk mematuhi kewajibannya dalam membayar pajak. Penelitian yang dilakukan oleh (Ananda et al., 2015) dan menyatakan bahwa tarif pajak berpengaruh positif terhadap kepatuhan wajib pajak UMKM.

Berdasarkan uraian tersebut, maka hipotesis yang dikembangkan dalam penelitian ini sebagai berikut.

$\mathrm{H}_{3}$ : Perhitungan Tarif Pajak berpengaruh pada kepatuhan pajak mahasiswa pelaku UMKM.

\section{METODE PENELITIAN}

Penelitian ini menggunakan metode penelitian asosiatif. Lokasi penelitian dilakukan di Program Studi Akuntansi Fakultas Ekonomi dan Bisnis Universitas Udayana. Lokasi tersebut dipilih karena program studi Akuntansi memiliki mata kuliah perpajakan yang diajarkan kepada mahasiswanya di semester 2 dan 3.

Populasi dalam penelitian ini adalah mahasiswa program studi akuntansi angkatan 2016 dan 2017 yang memiliki bisnis. Sampel pada penelitian ni adalah sampling jenuh, dimana seluruh populasi yang ada dijadikan sampel. Pada penelitian ni jumlah sampel adalah 30 orang. Teknik penentuan sampel dalam penelitian ni menggunakan teknik purposive sampling. Purposive sampling adalah metode pengambilan sampel berdasarkan kriteria-kriteria tertentu yang dianggap dapat mewakili objek yang akan diteliti (relevan) sesuai dengan tujuan penelitian. Kuesioner yang disebarkan kepada mahasiswa menggunakan satuan pengukuran skala Likert 4 poin, yaitu: poin 1 = sangat tidak setuju, poin $2=$ tidak setuju, poin 3 $=$ setuju, poin $4=$ sangat setuju.

Teknik analisis yang digunakan pada penelitian ni menggunakan regresi linier berganda, Model regresi linier berganda dalam penelitian ni ditunjukkan dengan persamaan sebagai berikut.

$Y=\alpha+\beta_{1} X_{1}+\beta_{2} X_{2}+\beta_{3} X_{3}+\varepsilon$

Keterangan :

$\mathrm{Y} \quad=$ Kepatuhan pajak

a $\quad=$ Konstanta

$\beta_{1} \quad=$ Koefisien regresi sosialisasi perpajakan

$\beta_{2} \quad=$ Koefisien regresi pengetahuan perpajakan

$\beta_{3} \quad=$ Koefisien regresi perhitungan tarif pajak

$\mathrm{X}_{1}=$ Sosialisasi perpajakan

$\mathrm{X}_{2} \quad=$ Pengetahuan perpajakan 
$\begin{array}{ll}\mathrm{X}_{3} & =\text { Perhitungan tarif pajak } \\ \varepsilon & =\text { error }\end{array}$

\section{HASIL DAN PEMBAHASAN}

Statistik deskriptif digunakan untuk menggambarkan atau mendeskripsikan mengenai data yang sedang diteliti dengan cara memberikan penjelasan mengenai data yang telah terkumpul sebagaimana adanya. Hasil dari uji statistik deskriptif dapat dilihat pada Tabel 2, sebagai berikut.

Tabel 2. Hasil Analisis Statistik Deskriptif

\begin{tabular}{llllll}
\hline Variabel & $\mathrm{N}$ & Minimum & Maximum & Mean & $\begin{array}{l}\text { Std. } \\
\text { Devitiation }\end{array}$ \\
\hline Sosialisasi Perpajakan & 30 & 14 & 44 & 32,76 & 7,837 \\
Pengetahuan Perpajakan & 30 & 12 & 48 & 35,06 & 8,662 \\
Perhitungan Tarif Pajak & 30 & 6 & 22 & 16,10 & 3,745 \\
Kepatuhan Pajak & 30 & 7 & 26 & 18,77 & 5,015 \\
\hline
\end{tabular}

Sumber: Data Penelitian, 2020

Sosialisasi Perpajakan $\left(X_{1}\right)$ memiliki nilai rata-rata (mean) sebesar 32,76 ini artinya ada kecenderungan nilai rata-rata mendekati nilai maksimum. Hal ini berarti sosialisasi perpajakan yang dimiliki mahasiswa cenderung tinggi. Nilai standar deviasi sosialisasi perpajakan sebesar 7,83. Nilai ini lebih rendah dibandingkan nilai rata-rata. Hal ini menunjukkan bahwa sebaran data berupa jawaban responden pada butir-butir pernyataan sosialisasi perpajakan dapat dinyatakan sudah merata atau rentang data satu dengan yang lainnya tidak tergolong tinggi.

Pengetahuan Perpajakan $\left(X_{2}\right)$ memiliki nilai rata-rata (mean) sebesar 35,06. ini artinya ada kecenderungan nilai rata-rata mendekati nilai maksimum. Hal ini berarti pengetahuan perpajakan yang dimiliki mahasiswa cenderung tinggi. Nilai standar deviasi pemahaman pengetahaun perpajaka sebesar 8,66. Nilai ini lebih rendah dibandingkan nilai rata-rata. Hal ini menunjukkan bahwa sebaran data berupa jawaban responden pada butir-butir pernyataan pemahaman pengetahuan dapat dinyatakan sudah merata atau rentang data satu dengan yang lainnya tidak tergolong tinggi.

Perhitungan Tarif Pajak memiliki nilai rata-rata (mean) sebesar 16,10. ini artinya ada kecenderungan nilai rata-rata mendekati nilai maksimum. Hal ini berarti pemahaman akan perhitungan tarif pajak yang dimiliki mahasiswa cenderung tinggi. Nilai standar deviasi perhitungan tarif pajak sebesar 3,74. Nilai ini lebih rendah dibandingkan nilai rata-rata. Hal ini menunjukkan bahwa sebaran data berupa jawaban responden pada butir-butir pernyataan perhitungan tarif pajak dapat dinyatakan sudah merata atau rentang data satu dengan yang lainnya tidak tergolong tinggi.

Kepatuhan Pajak memiliki nilai rata-rata (mean) sebesar 18,77 ini artinya ada kecenderungan nilai rata-rata mendekati nilai maksimum. Hal ini kepatuhan pajak yang dimiliki mahasiswa cenderung tinggi. Nilai standar deviasi kepatuhan pajak sebesar 5,01. Nilai ini lebih rendah dibandingkan nilai rata-rata. Hal ini menunjukkan bahwa sebaran data berupa jawaban responden pada butir-butir 
pertanyaan kepatuhan pajak dapat dinyatakan sudah merata atau rentang data satu dengan yang lainnya tidak tergolong tinggi.

Hasil dari uji asumsi klasik pada penelitian ini diolah dengan bantuan software SPSS 21 for Windows masing-masing dijabarkan sebagai berikut.

\section{Tabel 3. Hasil Uji Normalitas}

$\begin{array}{cc} & \text { Unstandardized Residual } \\ \mathrm{N} & 30 \\ \text { Kolmogorov-Smirnov Z } & 0,644 \\ \text { Asymp. Sig. (2-tailed) } & 0,801\end{array}$

Sumber: Data Penelitian, 2020

Hasil uji normalitas yang disajikkan dalam Tabel 3, menunjukkan bahwa nilai Asymp. Sig. (2-tailed) yaitu 0,801 lebih besar dari level of significant yaitu 5 persen $(0,05)$, ni menunjukkan bahwa data yang diuji berdistribusi normal.

Tabel 4. Hasil Uji Multikolinearitas

\begin{tabular}{lcc}
\hline \multirow{2}{*}{ Variabel } & \multicolumn{2}{c}{ Collinearity Statistic } \\
\cline { 2 - 3 } & Tolerance & VIF \\
\hline Sosialisasi Perpajakan $\left(\mathrm{X}_{1}\right)$ & 0,194 & 5,146 \\
Pengetahuan Perpajakan $\left(\mathrm{X}_{2}\right)$ & 0,260 & 3,845 \\
Perhitungan Tarif Pajak $\left(\mathrm{X}_{3}\right)$ & 0,269 & 3,720
\end{tabular}

Sumber: Data Penelitian, 2020

Nilai dari hasil uji multikolinearitas yang disajikkan menunjukkan bahwa, pada variabel sosialisasi perpajakan nilai tolerance $0,194>0,10$ dan nilai VIF 5,146 $<10$. Variabel pengetahuan perpajakan nilai tolerance $0,260>0,10$ dan nilai VIF $3,845<10$. Serta variabel perhitungan tarif pajak nilai tolerance 0,269 $>0,10$ dan nilai VIF 3,720 < 10. Sehingga dapat dinyatakan bahwa ketiga variabel bebas pada model regresi yang ada, tidak terjadi gejala multikolinearitas.

Tabel 5. Hasil Uji Heterokedastisitas

\begin{tabular}{lc}
\hline \multicolumn{1}{c}{ Variabel } & Sig. \\
\hline Sosialisasi Perpajakan $\left(\mathrm{X}_{1}\right)$ & 0,677 \\
Pengetahuan Perpajakan $\left(\mathrm{X}_{2}\right)$ & 0,854 \\
Perhitungan Tarif Pajak $\left(\mathrm{X}_{3}\right)$ & 0,438 \\
\hline
\end{tabular}

Sumber: Data Penelitian, 2020

Hasil uji heterokedastisitas yang disajikkan menunjukkan bahwa variabel sosialisasi perpajakan, pengetahuan perpajakan, dan perhitungan tarif pajak memiliki nilai Sig. yaitu lebih besar dari 0,05. Sehingga dapat disimpulkan bahwa tidak terjadi gejala heterokedastisitas pada variabel bebas dalam model regresi.

Pada penelitian ini diajukan tiga hipotesis. Ketiga hipotesis tersebut diuji dengan menggunakan analisis regresi linear berganda. Analisis regresi linear berganda digunakan untuk mengetahui pengaruh dari sosialisasi perpajakan, pengetahuan perpajakan, dan perhitungan tarif pajak pada kepatuhan pajak 
mahasiswa pelaku UMKM. Hasil dari analisis regresi linear berganda disajikan dalam Tabel 6 sebagai berikut.

Tabel 6. Hasil Analisis Regresi Linear Berganda

\begin{tabular}{|c|c|c|c|c|c|}
\hline \multirow[t]{2}{*}{ Model } & \multicolumn{2}{|c|}{$\begin{array}{l}\text { Unstandardized } \\
\text { coefficients }\end{array}$} & \multirow{2}{*}{$\begin{array}{c}\text { Standardized } \\
\text { coefficients }\end{array}$} & \multirow[t]{2}{*}{$t$} & \multirow[t]{2}{*}{ Sig. } \\
\hline & $\mathrm{B}$ & Std. Error & & & \\
\hline & $-2,286$ & 1,226 & & $-1,864$ & 0,074 \\
\hline 1 (Constant) & & & & & \\
\hline Sosialisasi Perpajakan & 0,213 & 0,078 & 0,332 & 2,772 & 0,011 \\
\hline $\begin{array}{l}\text { Pengetahuan } \\
\text { Perpajakan }\end{array}$ & 0,157 & 0,061 & 0,271 & 2,562 & 0,017 \\
\hline Perhitungan Tarif Pajak & 0,560 & 0,139 & 0,418 & 4,026 & 0,000 \\
\hline
\end{tabular}

Sumber: Data Penelitian, 2020

Berdasarkan Tabel 6, maka diperoleh persamaan regresi linear berganda sebagai berikut.

$$
Y=-2,286+0,213 X_{1}+0,157 X_{2}+0,560 X_{3}+\varepsilon
$$

Nilai konstanta (a) sebesar -2,286 memiliki arti bahwa apabila nilai sosialisasi perpajakan $\left(X_{1}\right)$, pengetahuan perpajakan $\left(X_{2}\right)$ dan perhitungan tarif pajak $\left(\mathrm{X}_{3}\right)$ dianggap konstan pada nilai 0 (nol), maka nilai kepatuhan pajak (Y) adalah sebesar $-2,286$.

Nilai koefisien sosialisasi perpajakan $\left(\mathrm{X}_{1}\right)$ yaitu 0,213 memiliki arti bahwa sosialisasi perpajakan berpengaruh terhadap kepatuhan pajak. Apabila sosialisasi perpajakan $\left(\mathrm{X}_{1}\right)$ meningkat sebesar satu satuan maka kepatuhan pajak $(\mathrm{Y})$ akan meningkat sebesar 0,213 dengan asumsi variabel bebas lainnya konstan.

Nilai koefisien pengetahuan perpajakan $\left(X_{2}\right)$ yaitu 0,157 memiliki arti bahwa pengetahuan perpajakan memiliki hubungan positif terhadap kepatuhan pajak. Apabila pengetahuan perpajakan $\left(\mathrm{X}_{2}\right)$ meningkat sebesar satu satuan maka kepatuhan pajak (Y) akan meningkat sebesar 0,157 dengan asumsi variabel bebas lainnya konstan.

Nilai koefisien perhitungan tarif pajak $\left(X_{3}\right)$ yaitu 0,560 memiliki arti bahwa perhitungan tarif pajak memiliki hubungan positif terhadap kepatuhan pajak. Apabila perhitungan tarif pajak $\left(X_{3}\right)$ meningkat sebesar satu satuan maka kepatuhan pajak (Y) akan meningkat sebesar 0,560 dengan asumsi variabel bebas lainnya konstan.

Tabel 7. Hasil Koefisien Determinasi ( $\left.\mathbf{R}^{2}\right)$

\begin{tabular}{ccccc}
\hline Model & $\mathrm{R}$ & $\mathrm{R}$ Square & Adjusted R Square & $\begin{array}{c}\text { Std. Error of the } \\
\text { Estimate }\end{array}$ \\
\hline 1 & 0,962 & 0,925 & 0,916 & 1,454 \\
\hline
\end{tabular}

Sumber: Data Penelitian, 2020

Pada uji koefisien determinasi dengan Adjusted $\mathrm{R}^{2}$ yang disajikkan, didapatkan hasil nilai dari Adjusted $\mathrm{R}^{2}$ adalah sebesar 0,925 atau 92,5 persen, ni berarti variasi kepatuhan pajak dapat dipengaruhi secara signifikan oleh variabel 
sosialisasi perpajakan, pengetahuan perpajakan dan perhitungan tarif pajak sebesar 92,5 persen, dan persentase sebesar 7,5 persen dijelaskan oleh faktorfaktor lain.

Tabel 8. Hasil Uji Kelayakan Model (Uji F)

\begin{tabular}{llrrrrr}
\hline & Model & Sum of Square & \multicolumn{1}{c}{ df } & Mean Square & F & Sig. \\
\hline 1 & Regression & 674,376 & 3 & 224,792 & 106,283 & 0,000 \\
Residual & 54,991 & 26 & 2,115 & & \\
Total & 729,367 & 29 & & & \\
\hline
\end{tabular}

Sumber: Data Penelitian, 2020

Pada uji kelayakan model (Uji F) yang disajikan didapatkan hasil bahwa signifikansi pada Uji F nilainya lebih kecil dari 0,05 (5 persen), sehingga dapat disimpulkan bahwa model regresi yang dibuat layak digunakan untuk menjelaskan pengaruh sosialisasi perpajakan, pengetahuan perpajakan dan perhitungan tarif pajak pada kepatuhan pajak mahasiswa pelaku UMKM.

Tabel 9. Hasil Uji Signifikansi Parsial (Uji t)

\begin{tabular}{lcc}
\hline \multicolumn{1}{c}{ Variabel } & t hitung & Sig. \\
\hline (Constant) & $-1,864$ & 0,074 \\
Sosialisasi Perpajakan $\left(X_{1}\right)$ & 2,772 & 0,011 \\
Pengetahuan Perpajakan $\left(X_{2}\right)$ & 2,562 & 0,017 \\
Perhitungan Tarif Pajak $\left(X_{3}\right)$ & 4,026 & 0,000 \\
\hline
\end{tabular}

Sumber: Data Penelitian, 2020

Hasil uji hipotesis pertama $\left(\mathrm{H}_{1}\right)$ menunjukkan bahwa pengaruh sosialisasi perpajakan pada kepatuhan pajak mahasiswa pelaku UMKM memperoleh nilai signifikansi (2-tailed) $\leq$ 0,05 yaitu 0,011, sehingga menyatakan bahwa $\mathrm{H}_{0}$ ditolak dan $\mathrm{H}_{1}$ diterima. Hasil ni memiliki arti bahwa sosialisasi perpajakan berpengaruh pada kepatuhan pajak mahasiswa pelaku UMKM. Hasil uji hipotesis kedua $\left(\mathrm{H}_{2}\right)$ menunjukkan bahwa pengaruh pengetahuan perpajakan pada kepatuhan pajak mahasiswa pelaku UMKM memperoleh nilai signifikansi (2-tailed) $\leq 0,05$ yaitu 0,017, sehingga menyatakan bahwa $\mathrm{H}_{0}$ ditolak dan $\mathrm{H}_{1}$ diterima. Hasil ni memiliki arti bahwa pengetahuan perpajakan berpengaruh pada kepatuhan pajak mahasiswa pelaku UMKM. Hasil uji hipotesis ketiga $\left(\mathrm{H}_{3}\right)$ menunjukkan bahwa pengaruh perhitungan tarif pajak pada kepatuhan pajak mahasiswa pelaku UMKM memperoleh nilai signifikansi (2-tailed) $\leq 0,05$ yaitu 0,000, sehingga menyatakan bahwa $\mathrm{H}_{0}$ ditolak dan $\mathrm{H}_{1}$ diterima. Hasil ni memiliki arti bahwa perhitungan tarif pajak berpengaruh pada kepatuhan pajak mahasiswa pelaku UMKM.

\section{SIMPULAN}

Berdasarkan pembahasan hasil yang diperoleh pada penelitian ini, maka dapat ditarik kesimpulan bahwa Sosialisasi perpajakan berpengaruh pada kepatuhan pajak mahasiswa pelaku UMKM. Sehingga, semakin sering mahasiswa mendapatkan nformasi dari sosialisasi perpajakan, maka kepatuhan pajak yang dimiliki juga akan meningkat. Pengetahuan perpajakan berpengaruh pada kepatuhan pajak mahasiswa pelaku UMKM. Sehingga, semakin baik pemahaman akan pengetahuan perpajakan yang dimiliki oleh mahasiswa sebagai wajib pajak UMKM, maka tingkat kepatuhan pajaknya akan meningkat. Perhitungan tarif pajak berpengaruh pada kepatuhan pajak mahasiswa pelaku UMKM. Sehingga, 
semakin mudah dipahami dan adil perhitungan tarif pajak yang diberikan kepada mahasiswa pelaku UMKM, maka kepatuhan pajak yang mereka miliki akan meningkat

Berdasarkan hasil dan pembahasan serta simpulan pada penelitian ini, adapun saran-saran yang dapat diberikan dalam penelitian ni, yaitu: 1) Bagi mahasiswa diharapkan dapat memahami dengan baik apa tu pajak, fungsi, serta manfaat pajak tu sendiri dan diharapkan mahasiswa dapat belajar dengan serius dalam memahami pengetahuan perpajakan karena lmu pajak wajib kita miliki sebagai masyarakat yang cinta pada tanah air dan sebagai modal kita nanti ketika lulus dari bangku kuliah dan menjadi karyawan ataupun wirausahawan. 2) Bagi nstansi perguruan tinggi disarankan agar meningkatkan kembali proses pembelajaran mata kuliah perpajakan dan meningkatkan sistem pembelajaran yang diterapkan agar tidak hanya berfokus pada materi perkuliahan melainkan berfokus pula pada kemampuan atau kapasitas peserta didiknya secara personal saat proses perkuliahan. 3) Bagi nstansi pemerintah disarankan agar lebih gencar lagi memberikan sosialisasi terkait pengetahuan perpajakan dan memfokuskan Pendidikan pajak kepada mahasiswa di bangku kuliah tidak hanya bagi mahasiswa ekonomi tapi juga jurusan lainnya, dan juga lebih memperhatikan keadilan bagi wajib pajak UMKM dalam perhitungan tarif pajak yang diberikan. 4) Bagi peneliti selanjutnya agar memperluas ruang lingkup penelitian sehingga tidak terbatas pada pada mahasiswa program studi akuntansi saja dan di Fakultas Ekonomi dan Bisnis saja.

\section{REFERENSI}

Adi, T. W. (2018). Pengaruh Pengetahuan Perpajakan, Sanksi Perpajakan dan Kesadaran Wajib Pajak terhadap Kepatuhan Wajib Pajak Badan pada KPP Pratama Cilacap. 53(9), 1689-1699. https:/ / doi.org/10.1017/CBO9781107415324.004

Akinboade, O. A. (2015). Correlates of Tax Compliance of Small and Medium Size Businesses in Cameroon. Managing Global Transitions.

Aladejebi, D. O. (2018). Measuring Tax Compliance among Small and Medium Enterprises in Nigeria. International Journal of Accounting and Taxation, 6(2), 29-40. https:// doi.org/10.15640/ijat.v6n2a4

Ananda, P. R. D., Kumadji, S., \& Husaini, A. (2015). Pengaruh Sosialisasi Perpajakan, Tarif Pajak, Dan Pemahaman Perpajakan Terhadap Kepatuhan Wajib Pajak (Studi pada UMKM yang Terdaftar sebagai Wajib Pajak di Kantor Pelayanan Pajak Pratama Batu). Jurnal Perpajakan (JEJAK. https:// doi.org/10.1145/3132847.3132886

Angelia, D. C., \& Fajriana, I. (2018). Pengaruh Sosialisasi dan Tingkat Pemahaman Terhadap Kepatuhan Setelah Penerapan Peraturan Pemerintah No 23 Tahun 2018 Pada Pelaku UMKM di Kota Palembang. (23), 1-15.

Astina, I. P. S. (2018). Pengaruh Pemahaman Peraturan Perpajakan, Kualitas Pelayanan Fiskus dan Kesadaran Wajib Pajak Terhadap Tingkat Kepatuhan WPOP. E-Jurnal Akuntansi, 23, 1-30. https:// doi.org/10.24843/EJA.2018.v23.i01.p01

Burhan, H. P. (2015). Pengaruh Sosialisasi Perpajakan, Pengetahuan Perpajakan, Persepsi Wajib Pajak Tentang Sanksi Pajak dan Impelementasi PP Nomor 46 Tahun 2013 Terhadap Kepatuhan Wajib Pajak Orang Pribadi ( Studi Empiris pada Wajib 
Pajak di Kabupaten Banjarnegara ). 4(2), 998-1012.

Cahyani, L. P. G., \& Noviari, N. (2019). Pengaruh Tarif Pajak, Pemahaman Perpajakan, dan Sanksi Perpajakan Terhadap Kepatuhan Wajib Pajak UMKM. E-Jurnal Akuntansi. https:// doi.org/10.24843/eja.2019.v26.i03.p08

Dlamini, B. (2017). Determinants of Tax Non-Compliance among Small and Medium Enterprises in Zimbabwe. Journal of Economics and Behavioral Studies. https:// doi.org/10.22610/jebs.v9i4.1837

Faizin, M. R., Kertahadi, \& Ruhana, I. (2016). Pengaruh Sosialisasi,Pemahaman,Dan Kesadaran Prosedur Perpajakan Terhadap Kepatuhan Wajib Pajak (Studi pada Wajib Pajak Orang Pribadi Pajak Bumi Bangunan Perdesaan dan Perkotaan di Desa Mojoranu Kabupaten Bojonegoro). Jurnal Perpajakan (JEJAK).

Fatmawati. (2015). Pengaruh Pemahaman Wajib Pajak Atas PP No. 46 Tahun 2013 dan Implementasi Self-Assessment System Terhadap Kepatuhan Wajib Pajak Dengan Persepsi Wajib Pajak Sebagai Variabel Moderasi (Studi Empiris Pada Pelaku UMKM Kerajinan Gerabah Kasongan). Skripsi Dipublikasikan. https:/ / doi.org/10.1145/3132847.3132886

Gitaru, K. (2016). The Effect of Taxpayer Education on Tax Compliance in Kenya. ( a case study of SME's in Nairobi Central Business District). (70986).

Hassan, N., Nawawi, A., \& Puteh Salin, A. S. A. (2016). Improving Tax Compliance Via Tax Education - Malaysian Experience. 15(2), 243-262.

Inasius, F. (2015). Tax Compliance of Small and Medium Enterprises: Evidence from Indonesia. Accounting and Taxation, 7(1), 67-73. https:// doi.org/10.1007/s13398-014-0173-7.2

Kuug, S. N. (2016). Factors Influencing Tax Compliance of Small and Medium Enterprises in Ghana. University of Ghana.

Manual, V., \& Zhi Xin, A. (2016). Impact of Tax Knowledge, Tax Compliance Cost, Tax Deterrent Tax Measures towards Tax Compliance Behavior: A survey on Self-Employed Taxpayers in West Malaysia. Electronic Journal of Business and Management, 1(1), 56-70.

Mukhlis, I., Utomo, S. H., \& Soesetio, Y. (2015). The Role of Taxation Education on Taxation Knowledge and Its Effect on Tax Fairness as well as Tax Compliance on Handicraft SMEs Sectors in Indonesia. International Journal of Financial Research. https:// doi.org/10.5430/ijfr.v6n4p161

Newman, W., \& Nokhu, M. (2018). Evaluating the impact of tax knowledge on tax compliance among small medium enterprises in a developing country. Academy of Accounting and Financial Studies Journal, 22(6), 1-14.

Oladipupo, A. O., \& Obazee, U. (2016). Tax Knowledge, Penalties and Tax Compliance in Small and Medium Scale Enterprises in Nigeria. IBusiness, 08(01), 1-9. https://doi.org/10.4236/ib.2016.81001

Setyorini, T. C. (2016). The Influence of Tax Knowledge, Managerial Benefit and Tax Socialization Toward Taxpayer's Willingness to Pay SME's Tax. Acta Universitatis Danubius. CEconomica), 12(5), 96-107.

Suntono, \& Kartika, A. (2015). Pengaruh Pemahaman Peraturan Pajak dan Pelayanan Aparat Pajak Terhadap Kepatuhan Wajib Pajak Dengan Preferensi Risiko Sebagai Variabel Moderasi (Studi Kasus Pada UMKM yang terdaftar di KPP Pratama Demak). Dinamika Akuntansi, Keuangan Dan Perbankan. 
Wahabu, A. (2017). Examining Tax Compliance of Small and Medium-Sized Enterprises in the Tamale Metropolis. Thesis, (January), 1-55.

Wardani, D. K., \& Wati, E. (2018). Pengaruh Sosialisasi Perpajakan Terhadap Kepatuhan Wajib Pajak Dengan Pengetahuan Perpajakan Sebagai Variabel Intervening (Studi Pada Wajib Pajak Orang Pribadi di KPP Pratama Kebumen). Nominal, Barometer Riset Akuntansi Dan Manajemen. https:// doi.org/10.21831/nominal.v7i1.19358

Wulandari, T., Andreas, A., \& Ilham, E. (2015). Pengaruh Sosialisasi Perpajakan, Pengetahuan Perpajakan, dan Kualitas Pelayanan Terhadap Kepatuhan Wajib Pajak DenganKesadaran Wahub Pajak Sebagai Variabel Intervening (Studi Pada KPP Pekanbaru Senalepan). Jurnal Online Mahasiswa Fakultas Ekonomi Universitas Riau.

Yulsiati, H. (2015). Analisis Pengaruh Sikap, Kesadaran Wajib Pajak, Pengetahuan Perpajakan dan Pemahaman Peraturan Perpajakan Terhadap Kepatuhan Wajib Pajak dalam Membayar Pajak Bumi dan Bangunan di Kecamatan Kemuning Kota Palembang. Jurnal Akuntanika.

Yusnidar, J., Sunarti, \& Prasetya, A. (2015). Pengaruh Faktor-Faktor yang Mempengaruhi Kepatuhan Wajib Pajak dalam Melakukan Pembayaran Pajak Bumi dan Bangunan Perdesaan dan Perkotaan (Studi pada Wajib Pajak PBBP2 Kecamatan Jombang Kabupaten Jombang). Jurnal Perpajakan (JEJAK), 1(1), $1-10$. 